\title{
US-China Trade War: Causes and Outcomes
}

\author{
${\text { Larisa } \text { Kapustina }^{1 *} \text {,Ludmila Lipková }}^{2}$, Yakov Silin $^{1}$, and Andrei Drevalev ${ }^{1}$ \\ ${ }^{1}$ Ural State University of Economics, Marketing and International Management Department of.465, \\ 62, 8 Marta St., Ekaterinburg, 620219, Russian Federation \\ ${ }^{2}$ University of Economics in Bratislava, International Economic Relations and Economic Diplomacy \\ Department, Dolnozemská cesta 1, 85235 Bratislava 5, Slovak republic
}

\begin{abstract}
The article reviews the chronology and analyses the causes and possible consequences of the trade war between the US and China. The authors identify four main reasons that led to the greatest trade conflict between the two economies in history associated with intentions of the US: a) to reduce the deficit of bilateral trade and increase the number of jobs; b) to limit access of Chinese companies to American technologies and prevent digital modernization of the industry in the PRC; c) to prevent the growth of China's military strength; and d) to reduce the federal budget deficit. It is confirmed and concluded that trade wars have no winners. Taking into account the two countries' GDP scale and export volumes, the US-China trade war will come amid a slowdown in the global production and international trade. The article analyses the outcomes of the trade confrontation based on the scenario methodology. The authors identify 4 scenarios by making assumptions about the response pattern and conjectural variation in the bilateral economic relations. The US protectionist policy has its political dimension. The constraints of the bilateral trade is one of the tools for slowing China's military and economic power growth.

Key words. trade war, protectionism, trade policy, economic sanctions, import tariff, trade balance, bilateral trade, high-tech capacity, global dominance, global supply chains
\end{abstract}

\section{Introduction}

Increasing economic power of China during the recent decades alongside with declining share of the United States in the global production and international trade in the beginning of the $21^{\text {st }}$ century has led to a change in the geopolitical landscape of the world and emergence of the "Group of Two", or simply G2.

China became the leader in commodity exports in 2015 and became a dominant player in international trade. China's absolute nominal GDP reaches USD 14092 million (with a share of $16.1 \%$ on world GDP, second place behind the US (USD 20412 million with $23.3 \%$ share of world GDP)). The absolute GDP by purchasing power parity is higher in China (USD 23159 million) compared to the US (USD 19390 million) [1]. The middle

\footnotetext{
*Corresponding author: lakapustina@bk.ru
} 
class is growing steadily: in 200280 million people belonged to the middle class in China, and in 2020 the middle class is expected to reach 700 million citizens of China, which will be about half of the total population [2]. China is the world's largest exporter with an annual export volume of USD 2,263.33 million, compared to the US exports of USD 1,546.72 million in the second place [3]. According to evaluation by some of the Chinese scientists, China's national economic power had surpassed that of the US in 2014: China has been the world's low-cost manufacturing centre and is becoming an export-oriented global technology hub [4]. Empirical studies with the use of econometric models have shown that China's economic influence has indeed increased, however, the America still holds leading position in all stock, credit, energy and commodity markets, and the US has remained the dominant power in the global economy. Therefore, there is still no unified understanding of the balance in the scale of the two economies in scientific literature [5].

The vision of its absolute dominance in the global economy in the US has come into conflict with the growing imbalance in bilateral trade with China, increasing competitiveness of high-tech companies based in the PRC, and an increase in China's investments exports. The US officials state that China is pursuing unfair trade policies, exploiting the benefits of trade liberalization and WTO membership, while at the same time keeping its domestic market safeguarded against foreign competition by providing subsidies and facilitating export through currency devaluation. The US accuses China of stealing scientific and technical knowledge and technologies from the American companies, violating the intellectual property rights and neglecting environmental protection requirements.

At the same time, researchers point out that when trying to "make America great again" D. Trump led the US to a direct violation of international law and multilateral agreements, guided exceedingly only by national interests. The protectionist trade policy of the US has been referred to as the policy of national egoism within the framework of the economic patriotism concept [6] and even economic terrorism [7]. The economic interests of the country's partners in the economic and political organizations and informal unions are neglected. It has become obvious that the US abandons the idea and the concept of free trade in order to preserve its status of the global leader which can result in spreading the deglobalization processes in the global economy, forming the regional mega-unions - as no country in the World can withstand the American protectionism without economic allies. The US is not interested in China's modernization, but the profound interdependence continues to contribute to development of the bilateral relationship [4].

Trade wars have no winners, as the global economy history proves. Both sides suffer losses, but the US has had a long record of winning negotiations on resolving trade contradictions and forcing other countries to step back. China has also shown its willingness to compromise, reduce the imbalance in bilateral trade to USD 200 billion and liberalize its domestic market for US companies. However, the requirements and sanctions imposed by the US have strong impact on the industrial policy of China and threaten the "Made in China 2025" plan. The latter implies that the PRC should secure leadership in 10 high-tech industries (robotics, artificial intelligence, etc.). The US is convinced that China's first successes in the implementation of the plan result from the use of American technologies and will try to restrict access to them for the China's industries.

Rafi Sheikh studies the US trade war with China and asks whether it is possible to win this war [8]. No trade war has the winner, but every trade war recognizes three losers: both trade partners and the global decline in trade, leading to a slowdown in the global economic growth. Carnegie addresses the issue of the escalation of Trump's trade war [9], Grossman and Helpman turn their attention to the issue of trade war and trade negotiations [10]. The current US-China trade war also involves negotiations which have led to many concessions, especially from a relatively highly protected Chinese market. Chunding, Chuntian, and 
Chungwei address the economic impact of a possible trade war [11]. In his article, Bouët asks whether trade wars are beneficial and whether they can be easily won [12].

The article aims to examine the causes, identify the scenarios of the trade war, outline the consequences for the US, China, and the global economy as a whole. An attempt is made to assess the development of the trade war between the American superpower and China as the potential global economic leader, taking into account the high degree of interdependence of the two economies, their mutual interest in maintaining presence in the largest markets. The topic is especially urgent and relevant as exporting and other international activities of the Group of Two as well as their direct confrontation influence the global GDP growth rates.

\section{Methodology}

In order to identify the causes and forecast the outcomes of the trade confrontation the article relies on the general scientific methods of analysis and synthesis. The authors analyse the statistics of the bilateral trade as well as the timeline of the trade war. The analysis highlights the milestones that reveal national interests of the two countries. Projecting the internal reasoning allows defining the aims and points of special importance for the both countries.

The outcomes are analysed based on the scenario methodology. The authors formulate four scenarios by drawing conclusions from the assumptions about the response pattern, conjectural variation in the bilateral economic relations and feedback intensity in terms of the systems theory: a) exacerbating feedback: conflict escalation in case of mirroring and matching responses with the tendency of intensification; the trade war will escalate into Cold War II, the sanctions will be applied to all the bilateral trade and will continue to intensify; b) balancing feedback: finding compromise solutions in case the countries reach consensus to avert the trade war; China will make considerable concessions; a significant part of the sanctions will be cancelled; c) zero response: new protectionist measures are not taken; the trade conflict is frozen on the already implemented bilateral measures, and the business makes extensive use of commercial schemes to circumvent sanctions; d) asymmetric response: trade war can escalate, involve military confrontation and lead to the Hot World War III.

\section{Chronology and causes of the trade war}

It is considered that March 23, 2018 was the formal date when the trade war began with D. Trump signing the "Presidential Memorandum Targeting China's Economic Aggression" and introducing tariffs on steel and aluminium [13]. However, the tensions in the economic relations of the US and China had appeared and were discussed earlier. The WTO granted China the status of a market economy in 2017, which aroused criticism from the US, because the decision limited opportunities for protectionism against companies from China. The US refused to recognize China as a market economy [14], which was the first step towards the confrontation within the "Group of Two". Trump's confrontational policy was reflected in the National Security Strategy, adopted in December 2017. It introduced restrictions on China's investments in American technology, tightened exports control and expanded the list of dual-use products that could not be shipped to China. The Entity List was introduced: US companies were banned from doing business with enlisted companies, including the ZTE Corporation which was accused of violating US sanctions against Iran. 
Table 1. Trade war milestones.

\begin{tabular}{|c|c|c|}
\hline $\begin{array}{c}\text { Time period, general } \\
\text { context }\end{array}$ & US actions & China's actions \\
\hline $\begin{array}{l}\text { April - May } 2017 \\
\text { Top-level negotiations to } \\
\text { resolve trade disbalances; } \\
\text { 100-day plan for trade talks }\end{array}$ & $\begin{array}{l}\text { Investigation on steel and } \\
\text { aluminium imports is initiated. } \\
\text { The US allows China to sell } \\
\text { cooked poultry to the US }\end{array}$ & $\begin{array}{l}\text { US companies get greater access } \\
\text { to China's agriculture, energy, } \\
\text { and financial markets }\end{array}$ \\
\hline $\begin{array}{c}\text { February - April } 2018 \\
\text { Investigation into China's } \\
\text { acts, policies and practices } \\
\text { relating to technology } \\
\text { transfer, intellectual property } \\
\text { and innovation. } \\
\text { The US initiates a WTO case } \\
\text { against China for } \\
\text { discriminatory licensing. } \\
\text { The US releases the official } \\
\text { statement (May 2018) } \\
\end{array}$ & $\begin{array}{l}\text { Global safeguard tariffs: } \\
30 \% \text { on solar panels; } \\
20 \% \text { on washing machines; } \\
25 \% \text { on steel imports; } \\
\text { 10\% on aluminium imports. } \\
\text { Measures targeting China: } \\
\text { restricting investment in key } \\
\text { technology sectors; imposing } \\
\text { import tariffs on aerospace, IT, } \\
\text { communication and machinery; } \\
\text { including ZTE in the Entity List }\end{array}$ & $\begin{array}{l}15-25 \% \text { tariffs on } 128 \text { product } \\
\text { categories including fruit, wine, } \\
\text { seamless steel pipes, pork and } \\
\text { recycled aluminium. } \\
178.6 \% \text { antidumping duties on } \\
\text { sorghum imports from the US }\end{array}$ \\
\hline $\begin{array}{c}\text { July } 2018 \\
\text { Ongoing negotiations; } \\
\text { internal discussion of the new } \\
\text { lists of restrictions }\end{array}$ & $\begin{array}{l}25 \% \text { tariff on } 818 \text { products } \\
\text { (imports worth } \$ 34 \text { billion) }\end{array}$ & $\begin{array}{l}25 \% \text { tariff on } 545 \text { products } \\
\text { (imports worth } \$ 34 \text { billion), } \\
\text { including agricultural products, } \\
\text { autos and aquatic products }\end{array}$ \\
\hline $\begin{array}{c}\text { August } 2018 \\
\text { The parties exchange } \\
\text { preliminary lists. } \\
\text { China files WTO claim and } \\
\text { complain against the US }\end{array}$ & $\begin{array}{l}25 \% \text { tariff on } 279 \text { goods (imports } \\
\text { worth } \$ 16 \text { billion) including: } \\
\text { semiconductors, chemicals, } \\
\text { plastics, motorbikes and electric } \\
\text { scooters }\end{array}$ & $\begin{array}{c}25 \% \text { tariffs on } 333 \text { goods (imports } \\
\text { worth } \$ 16 \text { billion) including: coal, } \\
\text { copper scrap, fuel, buses and } \\
\text { medical equipment }\end{array}$ \\
\hline $\begin{array}{c}\text { September } 2018 \\
\text { China cancels the trade } \\
\text { negotiations and releases the } \\
\text { White Paper stating the } \\
\text { official position }\end{array}$ & $\begin{array}{l}10 \% \text { tariff (announced subject to } \\
\text { further increase up to } 25 \% \text { in } \\
\text { 2019) on } \$ 200 \text { billion worth } \\
\text { imports from China }\end{array}$ & $\begin{array}{c}5 \% \text { and } 10 \% \text { tariffs on } \$ 60 \text { billion } \\
\text { worth imports }\end{array}$ \\
\hline $\begin{array}{l}\text { December } 2018 \\
\text { G20 summit in Buenos Aires. } \\
\text { The US and China agree not } \\
\text { to increase tariffs for } 90 \text { days }\end{array}$ & $\begin{array}{l}\text { The US announces that the new } \\
\text { list of tariffs will be delayed }\end{array}$ & \begin{tabular}{|c|} 
China increases import of \\
agricultural and energy products, \\
and lowers tariffs on cars and auto \\
products from $25 \%$ to standard \\
$15 \%$
\end{tabular} \\
\hline $\begin{array}{l}\text { May - June } 2019 \\
\text { Ongoing trade negotiations } \\
\text { before the G20 summit }\end{array}$ & $\begin{array}{c}25 \% \text { tariff (increase from } 10 \% \text { ) on } \\
\$ 200 \text { billion worth imports. } \\
\text { Huawei and five other companies } \\
\text { of China are added to the Entity } \\
\text { List }\end{array}$ & $\begin{array}{c}25 \%-20 \%-10 \% \text { tariffs introduced } \\
\text { for } \$ 60 \text { billion worth of imports } \\
\text { (increased from } 10 \%-10 \%-5 \% \\
\text { correspondingly) }\end{array}$ \\
\hline $\begin{array}{c}\text { June } 2019 \\
\text { G20 summit in Osaka. } \\
\text { The parties agree to avoid } \\
\text { increasing tariffs }\end{array}$ & $\begin{array}{l}\text { The ban on deals with Huawei is } \\
\text { reconsidered. } 110 \text { products are } \\
\text { excluded from the } 25 \% \text {-tariffs }\end{array}$ & $\begin{array}{c}\text { China announces its plans to } \\
\text { increase import of agricultural } \\
\text { products }\end{array}$ \\
\hline
\end{tabular}

Source: Authors' own elaboration based on [4].

Despite reaching the agreement at the G20 summit in Osaka, the parties very soon started exchanging threats to increase the tariffs. Chinese companies were reported to stop buying agricultural products from the US. The US accused China of currency manipulations aimed to gain competitive advantage and partly neutralize the effects of tariffs. China, in turn, initiated the third WTO case against the US questioning the reasons for imposing the tariffs. Neglecting the results of the G20 summit The US introduced a new list of tariffs on $\$ 125$ billion worth of imports from China. China then imposed 5\% tariff on 
US crude oil and other goods worth $\$ 75$ billion. The both parties later excluded some goods as it was becoming more and more evident that businesses of the both countries were paying too much for the actions of the governments.

Unilateral sanctions against ZTE and Huawei have significantly reduced their competitiveness and impeded the development of China's high-tech industries. China is unlikely to make significant concessions and abandon the development of the digital economy. On the contrary, it is likely to pursue the development of its own technologies, as well as put under boycott American goods and services.

In particular, one of the sensitive topics of the trade negotiations in agriculture is China's import of the US-produced soybeans. China had stopped importing soybeans from the US in July 2018 but resumed buying US soybeans in December 2018. Agricultural exports of the US have later been in the centre of negotiations. As a result, China excluded soybeans, as well as other farm products from additional tariffs in September 2019.

The US wants to increase the number of jobs by returning the US capital to its home country and conducting reindustrialization. And at the same the country seeks ways to reduce the costs of serving as a global leader. The Americans blame China for many of their problems [4]. By developing the Belt and Road Initiative, China also reduces American influence in the APR [15].

The causes of the US protectionist actions, and not only against China, can be identified as internal and external - from the perspective of the US own interests. Supporting domestic producers by limiting foreign competition can reduce overall consumption in the US but that will also increase the production volume of mainly steel and aluminium products to which increased tariffs apply. In addition to supporting domestic producers, the chronically passive balance of the US current account can also be considered to be the internal factor. Mutual trade with the PRC is a significant factor influencing the increasing current account deficit of the US.

We can identify four main causes, or incentives for the trade war between the US and China.

1. The trade war is supposed to reduce the deficit of bilateral trade and bring American jobs back home [4]. Out of the $\$ 796$ billion worth US trade deficit in 2017, China accounted for $\$ 376$ billion, or $47 \%$, almost a half [13]. The US acknowledges several problems in the trade with the PRC, the trade balance deficit being the most important one. The issue has been emerging for decades and still has an increasing trend (although the US trade deficit with China reached a historic low in May 2019). The US does not consider trading with China "fair" (figure 1).

Analysis of the commodity structure of exports and imports shows that China imports mainly American-interdependent products, while the US imports China's final products: "the US mechanical and electrical products from China are as high as $50 \%$ of the total of the top ten commodities in Sino-US trade. It can also be seen that the technological differences between China and the US in this field are not very large" [17].

Out of the total Chinese exports, $19 \%$ goes to the US. But only $8.3 \%$ of the US exports go to China [18]. In 2018, exports from the US to the PRC dropped by $21 \%$ as a result of the introduction of protectionist measures, but reduction was only by $12 \%$ in the trade flow from China to the US [19]. 


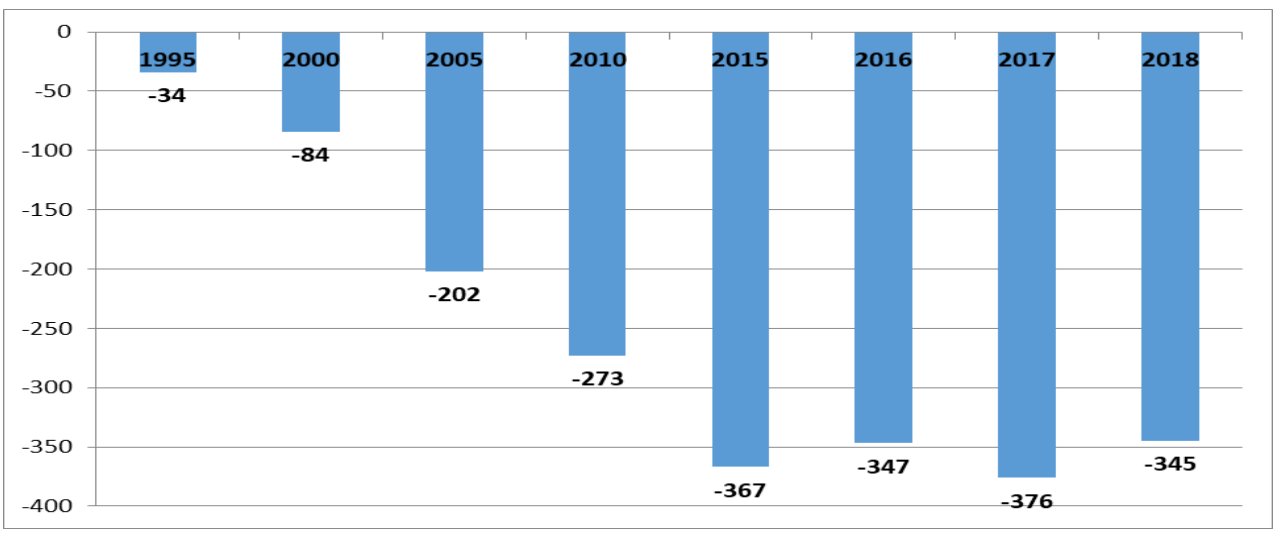

Fig. 1. US-China Trade Balance

Note: All values in the graph are in billions of USD.

Source: Authors' own elaboration based on [16].

2. The trade war is supposed to reduce high-tech capacity of China [4]. The US is not satisfied with China's requirements on creating joint ventures for technology transfer as a contribution to authorised share capital of local companies. Another sensitive topic is Chinese public investment creating unfair competition in global markets [14]. The US has been alerted by China's success in implementing a strategic plan for production modernization, increase in production of robots, lithium batteries, network equipment, etc. The US has increased import tariffs up to $25 \%$ on electronic products from China, including telecommunication and network equipment [13].

3. The trade war is supposed to prevent the growth of China's military strength. Markov believes that it is absolutely unacceptable for the US to let China achieve superiority in the military sector, even in the long run [20]. Consequently, the US is taking measures to ensure its competitive advantage in the national security sector and to prevent China from using American dual-use technologies.

4. The trade war is supposed to cut the federal budget deficit. According to Dongsheng Di, Gal Luft, \& Dian Zhong, "the US will need additional sources of income like tariffs in order to balance its budget, and tariffs on Chinese products is viewed as a main source of such income" [21]. The budget deficit of the US federal government grew and exceeded USD 21 trillion, which was attributed partly to tax cuts in December 2017. The Chinese government also has a much healthier fiscal position and is free to compensate any industries harmed by a trade war. By contrast, the US government is facing a large budget deficit of some 4 percent of GDP that is set to rise in the next few years [22].

\section{Outcomes and possible scenarios of the trade war}

The tensions in US-China trade relations threaten the entire global economy, not just the relations inside the Group of Two. As a result of the US-China trade cut, global growth can be expected to decline by $0.5 \%$ in 2020 [23].

The World Bank analysts have used a Computable General Equilibrium (CGE) Model to make an economic forecast: introduction of a $25 \%$ tariff on all goods of Chinese imports to the US will reduce world exports by $3 \%$ and the global product by $1.7 \%$. "The analysis shows that a US-China tariff escalation could reduce global exports by up to 3 percent (674 billion dollars) and global income by up to 1.7 percent (1.4 trillion dollars) with losses 
across regions". "The biggest declines in incomes are recorded by China and the US, up to $3.5 \%$ (USD 426 billion) and 1.6\% (USD 313 billion), respectively. The sectors most affected include: agriculture, chemicals and transport equipment in the US; and electronic equipment, machinery and other manufacturing in China" [24].

The OECD reckons that around a third of the content of the US imports from China is actually of foreign origin. The value added of China's exports to the US is perhaps USD 329 billion - some 2.7 percent of China's USD 12 trillion economy. So even if new tariffs slashed China's exports to the US by 25 percent, the direct hit to the China's GDP would be 0.7 percent. It would be a noticeable impact, but it would still leave the Chinese economy growing at 6.1 percent a year [22].

If exports from China to the US will be halved as a result of high import tariffs, then the direct loss of China's GDP will be at least $0.43 \%$. Taking indirect effects into account, the trade war will result in a $1.12 \%$ reduction in China's GDP. In case of imposing increased tariffs on all Chinese imports to the US, GDP losses will reach 4\% [25].

According to some experts, the response of China in the trade war with the US may be more painful for the American economy than for China [26]. American companies will partly lose their consumers in China because of nationalistic appeals to boycott products of American companies, including Apple, McDonald's, KFC. Alongside with that, the internal China's demand for the products restricted by the US (e.g. ZTE and Huawei) is increasing. Sanctions against ZTE have put the company in a very difficult position, because most of the chips for the telecommunication equipment production were imported from the US, and suppliers from China and Korea could not replace that amount [26].

The impact on consumers will depend on an individual's consumption choices. For example, those Americans who enjoy tech products, usually assembled in China, are likely to feel short-changed sooner than those relying on domestically (American) produced goods, as the imported goods are made more expensive by the increased tariffs applied. A recent study shows that imposing the tariffs on $\$ 200$ billion worth of the imports would cost each American household, on average USD 127 a year [27].

According to Bloomberg estimates, if all Sino-US mutual imports become subject to import tariffs, the global GDP will fall by USD 600 billion. And even if the trade war stops, previously implemented restrictions will result in 2 years' time in a slow-down of GDP growth by $0.2 \%$ in the US and by $0.5 \%$ in China [28].

Experts from China estimate the overall damage from the increase in US import tariffs from $0.3 \%$ to $0.7 \%$ of the PRC's GDP growth, which is a relatively "modest" estimation [13]. In particular, Terence Tai-Leung Chong \& Xiaoyang Li forecast that the trade war will reduce employment in China by $1.1 \%$ and GDP by $1.0 \%$, which may be considered not that sensitive for China [29].

C. Fred Bergsten has identified three scenarios for the development of a trade war: "a G0 in which the US is no longer willing to lead but China is not yet able or willing, and whether such (a likely) regime will be stable or unstable; a new G1, sooner or later, led by China; and a cooperative G2 in which the US and China agree to share leadership" [30]. We can foresee four scenarios of the further US-China trade war development.

\subsection{Scenario 1. Trade war will escalate into Cold War II.}

Cultural traditions and social values in the US and China are different. The countries will not give up their political and economic systems and will not transform them according to the practices imposed of suggested by the opposite side. China will have to reduce exportoriented production. In contrast to the Cold War I, China has a chance to win since it was able to build a competitive economy and form TNCs that made their way to the Global 500 . The US will surround China "with powerful American military capabilities, creating 
NATO-like adversarial alliances, isolating it economically and imposing costs when it did things the US did not like" [4].

China, in its turn, will seek to strive to push the US out from the APR. The US will explain its unilateral sanctions with the willingness to strike better deals, to reach an "honest" deal with China, but serving the interests of the US economy. The country will be achieving its goals by presenting ultimatums to its trade partner, if their national interests or security are considered harmed. As a result, more and more global problems will be addressed by unions of countries not involving the US (climate agreements, nuclear agreement with Iran, TPP - Trans-Pacific Partnership, China - EU summit in July 2018, etc.). The US will be gradually becoming isolated in the international community. The role of the US in global supply chains and international trade will decrease due to the deterioration of the country's authority. The US may be excluded from a number of regional trade and economic associations of countries. When some US companies are winning, others suffer losses. There is growing discontent among American business community and their overseas partners (with recent examples including Ford and Boeing, equipment manufacturing and chemical industry, etc.).

The US government bond market will suffer, inflation rate in the domestic consumer market will increase. The risk of unilateral economic sanctions imposed by the US will push other countries to search for alternative suppliers and markets.

China has become a leader in the Regional Comprehensive Economic Partnership (RCEP) of 16 countries, the scale of which expanded beyond the Comprehensive and Progressive Agreement for Trans-Pacific Partnership (CPTPP) without the US: $30 \%$ of global GDP, 50\% of the world population [20]. Exporting to RCEP countries from the PRC accounts for $26 \%$ of the total China's exports. The development of mega-union will strengthen the leading role of China in the region, but on the other hand, may also cause a decrease in international trade standards, since it does not cover issues of labor, human rights, e-commerce, public procurement [14].

At the same time, China's investment climate will suffer, the implementation of the "Made in China - 2025" plan is under the risk of failure, which may slow down technological progress in the country [14]. China has gradually increased its expenditure on R\&D, but it still lags behind the US. R\&D share in the GDP accounts for $2.1 \%$ and $2.8 \%$ respectively. According to Kerry Liu, in view of the importance of Made in China 2025 to economic future, it will be very difficult for China to make substantial concessions during the trade war [31].

\subsection{Scenario 2. Consensus to avert the trade war will be reached.}

A trade war will end with a compromise. It is possible if the US learns to respect the other parties' core interests and major concerns. China has already declared its readiness to open its car market, liberalize the banking sector, strengthen the protection of intellectual property rights, and limit the transfer of American technologies to Chinese business. China may agree to buy as much of the agricultural produce from American farmers as they can supply.

Edwin L.-C. Lai states that China is willing to seek a compromise and is ready to increase imports of goods and services from the US, cut down government subsidies to its businesses, and make the transfer of American technology more transparent [32]. However, it is not likely to cancel the increased import tariffs previously introduced by the US. The scenario does not exclude the possibility that the trade conflict can be frozen up for a long period of time: "Although deep and warm peace among great powers is rare in history, a cold peace or the US-China détente is a realistic goal" [4]. 
Both countries are deeply interested in exporting products and services on a bilateral basis and in developing global supply chains. The negotiated settlement agreement and the end of the war is possible, since both countries will lose more than they can gain as a result of the war. We can expect that China and the US will remain strategic partners despite the increased competition between them. Business-to-business ties will become closer, and mutual understanding of cultures will improve.

China will increase imports of LNG, agricultural raw materials and food, as well as high-tech products. The US administration will maintain a relationship of trust with major trading partners and will hold back from imposing unilateral sanctions, thus returning to respecting the WTO rules. The largest American companies will play a major role in this process by lobbying and promoting free trade and conveying the idea that a trade war against the whole world is not beneficial for the US.

\subsection{Scenario 3. The trade conflict is frozen on the already implemented bilateral measures.}

The trade war is becoming prolonged, high import tariffs are not cancelled. At the same time, companies in both countries are adapting to export-import operations under economic sanctions, developing commercial schemes to circumvent trade restrictions. It can be assumed inevitable to some extent because foreign economic relations are driven by companies who are main actors in the international economy, and not countries. Benefits of foreign activities are valuable incentives for companies to look for ways to circumvent sanctions and embargoes in order to preserve and increase profits. In this scenario the imbalance in trade between the US and China will be decreasing and - according to official statistics - will reach a target level of USD 200 billion, possibly even less than that. However, in fact, the goods of Chinese origin will be supplied to the American market from other countries, e.g., neighbouring countries in the APR.

As Vinogradov, Salitsky and Semenova note, Chinese companies have already begun to move production units to Vietnam, Bangladesh, Ethiopia and other countries with relatively cheap labor, given the fact that China largely exports products of TNCs that have placed final assembly production units in the PRC. Foreign firms account for 59\% of Chinese exports to the US, and 12\% are products of American companies located in China [13]. China's exports to the US are typically Chinese-assembled goods that contain many foreign parts and components - and are often American-branded. A further 37 percent of the US imports from China consist of parts and components on which US-based manufacturers rely.

TNCs have begun to restructure their global supply chains and may move the final assembly of goods from China to neighboring Asian countries. It will result in changes in the geographic structure of China's exports and imports. While maintaining the final assembly in China, the intermediate links of the global production chain can be made cheaper. For example, China supplies USD 2 billion/year worth iPhones to the US, but only a small part of the product's value is created in China, since the gadget is made in Taiwan of components supplied from many countries: Germany, Korea, Japan, the USA, The Netherlands, Singapore, etc. [6]

Trade wars lead to changes in export-import flows, orientation to other countries, emergence of regional free trade zones and economic alliances. Lawrence J. Lau notes the shift in China's foreign economic relations focus to such countries and regions as the EU, ASEAN, Japan and Russia [25]. Analysts have identified a trend towards intensifying China-EU trade and economic ties, and moreover, the Asian market is becoming more important for European business than that of the US [14]. Consumer spending has grown four times faster in China than in the US in the last decade. Badar Alam Iqbal \& Nida 
Rahman believe that the trade war will result in losses for both conflicting parties but it might come as a benefit for other countries: "Being the two largest economies of the world, giving in for disengaging trade with each other is bound to have a ripple effect on the global system of trade" [33]. In the view of the US protectionism, countries with large domestic markets will be the ones to gain a competitive advantage.

Since the beginning of the trade war, alongside with the US limiting imports from China, six countries in Southeast Asia and Taiwan have organized supplies of nearly 1,600 new categories of goods that they have never sold in the US before [34].

At the same time the Chinese market is crucial for many US companies, therefore restricting access to Chinese consumers causes great financial damage to corporations [7]. As the result, the companies seek possible ways to circumvent sanctions and to lobby and promote their business interests. Under this scenario, the US will achieve its goal of reducing the trade deficit in bilateral trade with China, but with poor economic efficiency.

\subsection{Scenario 4. Trade war will escalate into Hot World War III}

A trade war can escalate from Cold to Hot stage, which is especially unwanted scenario considering that the US allows limited use of nuclear weapon. According to Terence TaiLeung Chong \& Xiaoyang Li, the trade conflict between China and the US is of fundamental nature and it cannot be easily resolved [29]. The conflict is associated with the race for global economic domination. The US has a serious advantage in cyberspace and it seeks to "digitally colonize" the global economy. According to Ashmanov, almost all neural platforms in the world are US-based, including first of all those belonging to Google and Facebook [35]. "The US shows with its actions, that they are ready to easily throw any inconvenient contracts and obligations away into the trash can, and also to ignore the UN and other international organizations, granting itself the right for unilateral military actions, the US is moving towards the role associated with the British Empire after the World War I" [6]. This scenario seems unlikely now, but it is not excluded.

Trump has made matters worse by acting unilaterally against China in a way that would appear to breach World Trade Organization rules. Indeed, potential allies find Trump's "America First" rhetoric repulsive. All this has given China the political high ground "China doesn't want a trade war, but we're not afraid to fight a trade war" has become Beijing's official line [22].

\section{Conclusion}

The greatest trade war in economic history can result in a change in the international trade architecture, slow-down of financial markets. The countries can be divided into two blocks supporting the US or China, and at the same time, forming the mega-alliances of economies, as well as regional currency zones. The Asia's role in globalization processes and the development of global supply chains is likely to strengthen. The US strives to weaken its main competitor and maintain dominance in the global arena: in the economy, politics and the national security.

The current foreign trade policy of the US aims to slow down the still rapid economic growth of the PRC and its growing importance in the world economy. The China's government in its turn has a goal to achieve leadership in robotics, biotechnology and artificial intelligence. It will provide financial support to high-tech industries, and will do everything possible not to let the US stop or slow down the modernization and digitalization of the China's economy.

The current situation in US-Chinese trade relations is referred to as the Cold Trade War. The common economic interests of both countries are more significant than disputes. The 
mutual interdependence of both economies has led to negotiations that will result in a new "fairer" trade agreement. The new US-China trade agreement should include the so-called a new trade architecture that will regulate not only the use of classical tools in mutual trade such as tariffs, quotas, and sanitary and phytosanitary certificates, but also other regulations as well as intellectual property protection, technology transfers, and Chinese state subsidies to manufacturers and exporters. The new agreement will also deal with questions beyond trade, such as cyber espionage and the expansion of US firms' access to the Chinese market.

Finally, we note that the US protectionist attack on their trading partners, especially on the People's Republic of China, has a political dimension in addition to its economic dimension. China is designated by the US leaders as the US' chief strategic rival in the future. Therefore, various constraints of trade with the US and other ways to slow down China's economic growth are also tools for slowing China's political power growth.

\section{References}

1. Statistics Times, List of Countries by GDP (PPP) [online], Available at: http://statisticstimes.com/economy/countries-by-gdp-ppp.php (2018)

2. Statista, Number of the middle class population in China in 2002 and 2020 (in millions) [online], Available at: https://www.statista.com/statistics/875874/middleclass-population-in-china (2019)

3. Statista, Top 20 export countries worldwide in 2017 (in billion U.S. dollars) [online], Available at: https://www.statista.com/statistics/264623/leading-export-countriesworldwide/ (2019)

4. Z. Suisheng, D. Guo, A New Cold War? Causes and Future of the Emerging US-China Rivalry. Vestnik RUDN. International Relations, 19(1), 9-21 (2019)

5. D. Zhang, L. Lei, Q. Ji, A.M. Kutan, Economic policy uncertainty in the US and China and their impact on the global markets. Economic Modelling, 79, 47-56 (2019)

6. Y.A. Savinov, A.N. Zelenuk, E.V. Taranovskaja, G.A. Orlova, A.V. Skurova, Increased protectionism in US trade policy. Russian Foreign Economic Bulletin, (1), 36-51 (2019)

7. I. Sinitsyn, P. Kuimov, The economic terrorism of the USA with regard to Europe, Russia and other countries. Vlast, (9), 236-241 (2018)

8. S. Rafi Sheikh, Les États-Unis ne pourront pas gagner la guerre commerciale contre la Chine [online] Available at: https://www.mondialisation.ca/les-etats-unis-nepourront-pas-gagner-la-guerre-commerciale-contre-la-chine/5626497 (2018)

9. A. Carnegie, Trump's Trade War Escalates [online], Available at: https://www.foreignaffairs.com/articles/2018-06-25/trumps-trade-war-escalates (2018)

10. G.M. Grossman, E. Helpman, Trade wars and trade talks. Journal of Political Economy, 103(4), 675-708 (1995)

11. L. Chunding, H. Chuantian, L. Chuangwei, Economic Impacts of the Possible ChinaUS Trade War. Emerging Markets Finance and Trade, 54(7), 1557-1577 (2018)

12. A. Bouët, Les guerres commerciales sont-elles bonnes et faciles à gagner? [online], Available at: http://parisinnovationreview.com/article/les-guerres-commerciales-sontelles-bonnes-et-faciles-a-gagner (2018)

13. A.O. Vinogradov, A.I. Salitsky, N.K. Semenova, US-China Economic Confrontation: Ideology, Chronology, Meaning. Vestnik RUDN. International Relations, 19(1), 35-46 (2019) 
14. S.I. Dolgov, Y.A. Savinov, International trade: USA on the warpath. Russian Foreign Economic Bulletin, (9), 7- 20 (2018)

15. Y. Silin, L. Kapustina, I. Trevisan, A. Drevalev, China's economic interests in the "One Belt, One Road" initiative. SHS Web of Conferences: Innovative Economic Symposium 2017 - Strategic Partnership in International Trade, 39 (2017)

16. US Census Bureau, Trade in Goods with China [online], Available at: https://www.census.gov/foreign-trade/balance/c5700.html (2019)

17. Y. Deng, F. Pan, Dependence analysis of Sino-US trade. Journal of Physics: Conference Series, 1176(4) (2019)

18. Statista, Total value of U.S. trade in goods (export and import) worldwide from 2004 to 2018 (in billion U.S. dollars) [online], Available at: https://www.statista.com/statistics/218255/total-value-of-us-trade-in-goods-worldwidesince-2004/ (2019)

19. US Census Bureau, Trade in Goods with China [online], Available at: https://www.census.gov/foreign-trade/balance/c5700.html (2019)

20. V.V. Markov, China and the USA: From economic rivalry in Asia-Pacific to trade war. The Herald of the Diplomatic Academy of the MFA of Russia. Russia and the World, 4(18), 110-119 (2018)

21. D. Dongsheng, G. Luft, D. Zhong, Why did Trump launch a trade war? A political economy explanation from the perspective of financial constraints. Economic and Political Studies, 7(2), 203-216 (2019)

22. P. Legrain, Why China will win the trade war [online], Available at: https://foreignpolicy.com/2018/04/13/why-china-will-win-the-trade-war (2018)

23. A.N. Da Costa, The early victims of Trump's trade war [online], Available at: https://www.bbc.com/news/business-45028014 (2018)

24. C. Freund, M. Ferrantino, M. Maliszewska, M. Ruta, Impacts on global trade and income of current trade disputes. Macroeconomics, Trade Investment (MTI) Practice Notes, 2, 11 (2018)

25. L.J. Lau, The sky is not falling! Economic and Political Studies, 1-26 (2019)

26. Y. Wang, Last warning: what US Hi-Tech companies lose in trade war with China [online], Available at: https://www.forbes.ru/tehnologii/360641-posledneepreduprezhdenie-chto-poteryayut-tehnologicheskie-kompanii-ssha-v (2018)

27. Q. Bui, N. Irwin, How Much Will the Trade War Cost a Typical American Family? Around $\$ 60$ (So Far) [online], Available at: https://www.nytimes.com/interactive/2018/07/12/upshot/trade-war-cost-families.html (2018)

28. B. Holland, C. Sam, A $\$ 600$ Billion Bill: Counting the Global Cost of the U.S.-China Trade War [online], Available at: https://www.bloomberg.com/graphics/2019-uschina-trade-war-economic-fallout/ (2019)

29. T.T.L. Chong, X. Li, Understanding the China-US trade war: causes, economic impact, and the worst-case scenario. Economic and Political Studies, 7(2), 185-202 (2019)

30. C.F. Bergsten, China and the United States: The Contest for Global Economic Leadership. China \& World Economy, 26(5), 12-37 (2018)

31. K. Liu, Chinese manufacturing in the shadow of the China-US trade war. Economic Affairs, 38(3), 307-324 (2018) 
32. E.L.C. Lai, The US-China trade war, the American public opinions and its effects on China. Economic and Political Studies, 7(2), 169-184 (2019)

33. B.A. Iqbal, N. Rahman, J. Elimimian, The future of global trade in the presence of the Sino-US trade war. Economic and Political Studies, 7(2), 217-231 (2019)

34. N. Dembinskaya, How Beijing bypasses American bans in trade war [online], Available at: https://ria.ru/20190607/1555320044.html (2019)

35. D. Smirnov, Can the West with one click of a computer turn off our factories, banks and power stations [online], Available at: https://www.ural.kp.ru/daily/26992/4053140 (2019) 